\title{
REGULATING HUMAN RESEARCH
}


This page intentionally left blank 


\section{REGULATING}

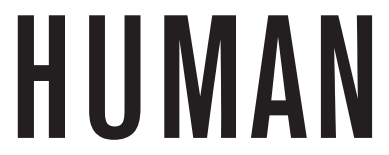

RESEARCH

IRBS from Peer Review to Compliance Bureaucracy

SARAH BABB 
STANFORD UNIVERSITY PRESS

Stanford, California

(C) 2020 by the Board of Trustees of the Leland Stanford Junior University. All rights reserved.

No part of this book may be reproduced or transmitted in any form or by any means, electronic or mechanical, including photocopying and recording, or in any information storage or retrieval system without the prior written permission of Stanford University Press.

Printed in the United States of America on acid-free, archival-quality paper

LIBRARY OF CONGRESS CATALOGING-IN-PUBLICATION DATA

Names: Babb, Sarah L., author.

Title: Regulating human research : IRBs from peer review to compliance bureaucracy / Sarah Babb.

Description: Stanford, California : Stanford University Press, 2020. | Includes bibliographical references and index.

Identifiers: LCCN 2019019676 (print) | LCCN 2019021745 (ebook) | ISBN 9781503611238 (electronic) | ISBN 9781503610149 (cloth : alk. paper) | ISBN 9781503611221 (pbk. : alk. paper)

Subjects: LCSH: Institutional review boards (Medicine)—United States. | Human experimentation in medicine-Law and legislation-United States. | Medical ethics committees-United States. | Bureaucracy-United States. Classification: LCC R852.5 (ebook) | LCC R852.5 .B33 2020 (print) | DDC $174.2 / 8$ - dc23

LC record available at https://lccn.loc.gov/2019019676

Cover design: Christian Fuenfhausen

Typeset by Westchester Publishing Services in 10/14 Minion Pro 
To my father, Alan Babb, who got me thinking about this topic, who gave me a title, and whose insight and encouragement helped me get to this book. 
This page intentionally left blank 